\title{
A TELEPÍTÉSI DÖNTÉSEK ÁRNYOLDALAI
}

Az új létesítmények elhelyezéséról szóló döntések általában kiemelt fontosságúak a vállalatok, az állami szervek vagy más szervezetek életében. A pozitív hatások felemlegetése mellett ritkábban hallani a telepítési döntések árnyoldalairól: azok sokszor a helyi közösségek hangos ellenállásába ütköznek. A helyi érintett csoportok számára ugyanis a létesítmények a legtöbb esetben új kockázatok és tényleges negatív hatások megjelenését is jelentik. A tanulmány ezeknek a különböző kockázatpercepciók kialakulását magyarázza, és kísérletet tesz a telepítési döntések körüli konfliktusok megoldási lehetôségeinek vázolására is az eltérö megközelítések szemüvegein keresztül. ${ }^{1}$

\section{Kulcsszavak: beruházások, telepítési döntések, kockázatkezelés}

A vállalati növekedés csalhatatlan jele az új üzemek, szolgáltató központok létrehozása vagy a meglévő létesítmények bővítése. Az új gyárak, üzemek elhelyezése a kiemelt fontosságú stratégiai döntések közé tartozik (Chikán - Demeter, 1999). Az új létesítmény földrajzi koordinátái az egész vállalatra nézve meghatározóak lehetnek: az erőforrásokhoz való hozzáférés, a piaci közelség alapvető szempontok lehetnek a döntésben. A vállalat versenyképességét nagyban javíthatja, ha olyan helyszínt sikerül kiválasztania újabb létesítményeinek, amely megfelelő potenciált biztosíthat a sikeres múködéshez, illetve a további növekedéshez.

A szempontok mérlegelésénél azonban gyakran elsikkad, hogy a helyi társadalmi környezet - a helyi vállalkozók, a helyi lakosság vagy éppen az érintett önkormányzatok - hogyan fogadják majd a létesítményelhelyezés tényét. Legtöbbször azt feltételezzük, a helyi érintettek kapva kapnak az új beruházás után, és ezt sugallja a sajtóban napvilágot látott nemzetközi és magyarországi telepítési döntések sokasága is. Nemzetállamok, régiók és települések állnak sorban azért, hogy multinacionális vállalatok, állami intézmények vagy más befektetók náluk hozzák létre soron következő beruházásaikat, és számos kedvezményt biztosítanak azért, hogy az adott országban, régióban vagy településen új termelő vagy szolgáltató egységeket hozzanak létre munkahelyeket és adóbevételeket teremtve a gazdaságnak.
A helyi érdekcsoportok reakciói ugyanakkor sokszor beámyékolják a fenti sikertörténeteket, többször kiderül: az új beruházó fogadtatása helyi szinten nem mindig olyan meleg, mint amilyet a kormányzat, a régió vezetése vagy az önkormányzati képviselő-testület tanúsít iránta. A beruházó üzemek ugyanis nemcsak munkahelyeket vagy növekvő adóbevételeket jelentenek a településnek (vagy tágabb értelemben a térségnek), ahová az új beruházás irányul, hanem különböző kockázatokat vagy biztos negatív következményeket is: a megépülő létesítmények nem várt környezetterhelést jelenthetnek, a lokális kultúrát veszélyeztethetik, helyi vállalkozások megélhetését tehetik tönkre. Ebben a tanulmányban a környezeti kockázatokkal foglalkozom kiemelten, és azt vizsgálom, hogy a telepítési döntésekre hogyan hat a helyi érdekcsoportok kockázatészlelése, és milyen konfliktusok forrásai lehetnek a rosszul kivitelezett telepítési döntések.

\section{Mi a telepítési probléma?}

Telepítési döntésnek tekintünk minden olyan döntési folyamatot, amely valamilyen létesítmény helyszínének kijelölésére, illetve annak térbeli elhelyezésére vonatkozik. A telepítési döntések sajátos környezeti kockázatokat hordoznak magukban, maga a létesítési folyamat, illetve hosszabb távon a létesítmények fenntartása és múködtetése a legtöbb esetben negatívan érintheti 
a létesítmény közvetlen, illetve tágabb környezetét. E kockázatok felismerése konfliktusokat gerjeszthet a beruházók (a döntéshozók) és a döntés más érintettjei között. Ebben a tanulmányban érintettként tekintek minden olyan egyénre vagy csoportra, aki vagy amely befolyásolhatja a döntéshozók célmegvalósítását, vagy érintve van abban ${ }^{2}$. Bár az elốbbi meghatározás igen tágan húzza meg egy döntés lehetséges érintettjeinek a körét, elemzésemben elsősorban a helyi érintettek: a lakosság, helyi érdekvédő csoportok, önkormányzatok szerepére összpontosítok. Nem ritka azonban az sem, hogy egy telepítési döntés kapcsán nemcsak helyi, hanem regionális vagy országos csoportok is hallatják hangjukat.

FrankPopper 1981-ben használta legelőször a LULU (Locally Unwanted Land Uses - helyi szinten nemkívánatos földhasználat) fogalmát. Ilyen lehet a szükséglakások, erőmúvek, repülő́terek, szennyvíztisztító telepek, börtönök, külszíni bányák, energiavezetékek, autópályák, duzzasztógátak, olajfinomítók, vasútvonalak, hulladékudvarok, temetók, szórakoztató parkok vagy éppen kocsmák létesítése, katonai létesítmények építése (Popper, 1981). Egyetlen szóval valószínúleg nehezen lehetne leími, hogy miért váltanak ki a fenti létesítmények olykor rendkívül heves ellenállást. A fizikai ártalmaktól való félelem éppúgy közrejátszhat az ellenérzés kialakulásában, mint az attól való aggodalom, hogy a befogadó település megbélyegzetté válik, és az ingatlanárak így esni fognak. Egyes negatív hatások bizonyosak (például egy vegyipari üzem átadása után a környéken élốk számára a levegőszennyezés biztosan növekedni fog), mások csak nagyon kis valószínúséggel kövezhetnek be, igaz, akkor néha katasztrofális következményekkel (mint mondjuk egy atomhulladék-lerakó szivárgása). A negatív egészségügyi és gazdasági hatások mellett gyakran felmerülhetnek ugyanakkor olyan negatív társadalmi hatások is, mint a társas hálózatok széttöredezése vagy a helyi kultúrák sokszor visszafordíthatatlan megváltozása (Lesbirel, 2003).

A fenti létesítmények telepítése kapcsán a LULU betứszó mellett egy másik rövidítés is beépült a köztudatba: a NIMBY (Not In My Back Yard - ne az én kertembe). A NIMBY jelenség fontos többlettel rendelkezik a helyi szinten nemkívánatos földhasználathoz képest. A „ne az én kertembe" elnevezést ugyanis elsősorban olyan beruházásoknál használják, ahol a beruházás jogosságát még a létesítmény elutasítói is elismerik (egy szemétégetốre például országos vagy regionális szinten szükség lehet, hiszen anélkül a szemét kezelése problematikussá válhat), csak azt kérdôjelezik meg, hogy ennek a létesítménynek pont az ő lakóhelyük környékén kell megépülnie.

\section{A technokrata megközelítés}

A telepítési döntések irodalmának első munkái elsôsorban azt kutatták, hogyan lehet elhelyezni különbözó létesítményeket a legalacsonyabb költségszintek mellett. A hetvenes évek végéig, a nyolcvanas évek elejéig a kutatások kevéssé vizsgálták a telepítési döntések szocioökonómiai hatásait, a kutatók elsősorban technikai, illetve technológiai kérdésekkel foglalkoztak. A megközelítést a szakirodalomban néhol mérnöki, máshol top-down (Freudenburg, 2004), esetleg zárt (Kuhn - Ballard, 1998) vagy ortodox (Davy, 1996) jelzókkel illetik, de mindegyikben közös, hogy a vizsgálódások fókuszában legtöbbször az áll: milyen módszertani megoldásokkal lehet kiválasztani azt a legjobb alternatívát, ami valamilyen (általában negatív környezeti hatású) létesítmény helyszínéül szolgálhat. A döntés legfontosabb szempontjai között megtalálhatjuk a profitabilitást, a funkcionalitást, a biztonságot és a jogi követelményrendszer betartását. Így nem véletlen, hogy a hagyományos telepítési modell szerint a döntés elsősorban a közgazdászok, a mérnökök, a tervezők és az ellenőrző hatóságok feladatköre, hiszen ók azok, akik leginkább befolyásolni képesek az elóbbi négy kritériumot (Davy, 1996). Ez a fajta technikai megközelítés az évek során továbbra is népszerú terület maradt a kutatók között, akik elsősorban az operációkutatás eszköztárára hagyatkoztak a legjobb módszerek kifejlesztésekor. Ebben az értelemben ugyanis a telepitési döntés többdimenziós döntésként értelmezhetó, ahol az adott létesítmény helyszinének számos szempontnak (földrajzi, biológiai, technológiai stb.) kell megfelelnie, és ezek fényében kell az optimális alternativát kiválasztani.

Fontos leszögezni, hogy ez a fajta technikai megközelítés nem feltétlenül jelenti azt, hogy ökológiai vagy társadalmi megfontolások kimaradnak az elemzésből. Bennedsen és Kirkwood (1982) például olyan többlépcsős kiválasztási folyamatot ajánlanak, amely először a lehetséges régiók szelektálását végzi el, ezt követően az elfogadható helyszíneket választja ki, és végül a lehetséges helyszínek sorrendjének a felállítását a hozzájuk kapcsolódó várható hasznosságok kiszámításával éri el. A várható hasznosságok kalkulációját átfogó érzékenységvizsgálat követi, teljessé téve az elemzést. A szempontok közé így bekerülhetnek technológiai kérdések, ökológiai megfontolások, költségszempontok is. A többlépcsős döntéshozatali eljárás lehetővé teszi, hogy eltérő filozófiájú döntési módszertanokat alkalmazzunk a kiválasztás különböző fázisaiban. A régió és a lehetséges helyszínek kiválasztásakor elsősorban szúrőmodelleket alkalmazhatunk, amelyek azokat a helyszíneket rostálják ki, melyek semmikép- 
pen sem lehethek egy új létesítmény befogadói. (Ilyen lehet például egy nemzeti park területe, vagy egy széntüzelésú erőmú esetén olyan földrajzi alakzatok, ahol a felszín esése nagyobb tíz százaléknál.) A lehetséges helyszínek közül azonban már számszerúsítő modellek segítségével választhatunk ${ }^{3}$. Az additív hasznossági függvényben az előzóleg meghatározott szempontok szerint értékeljük a lehetséges helyszíneket, és a végleges rendezést súlyozással kapjuk meg. A súlyok megállapítását egy multidiszciplináris szakértói csapat végzi, a felmerülő lehetséges átváltások (trade-off) mérlegelésével. A hasznossági függvényt végül a beruházók tekintik át, majd alkalmazzák a lehetséges helyszínekre.

A folyamat utolsó lépésével - a legjobb helyszín kijelölése és bejelentése a közvéleménynek - elvileg lezárul a telepítési folyamat. A technokrata modellek általában nemigen számolnak azzal, hogy a tudományosan alátámasztott döntéssel szemben a helyi érdekcsoportok bármilyen kifogást támaszthatnak, illetve az érintettek meglátásait sem csatornázzák be a döntési folyamatba, a beruházók a technikai eljárás végén már csak tájékoztatják ốket a döntés végeredményéról, esetleg köztes nyilvános közmeghallgatásokon csak formálisan vonják be a helyieket a döntésbe - erre utal a top-down jelző (Kuhn - Ballard, 1998).

A technokrata megközelítés népszerüsége a szakirodalomban és a gyakorlatban egyaránt a mai napig töretlen. A technikai eljárások korlátait még sokszor népszerúsítóik is elismerik, mások viszont sokkal vehemensebben támadják a megközelítést. Az ellenzốk szerint le kellene számolni azzal az illúzióval, hogy a kockázatokra (értsd a károk, kataszurófaesemények bekövetkezési valószínúségére és mértékére) objektív becslés adható, és azt is fontos lenne beismerni, hogy az „objektív” kockázatelemzést végző szakértók legtöbbször valamelyik érdekcsoport megbízásából tevékenykednek, akik véleményében óhatatlanul tükröződni fog a képviselt csoport véleménye (Kunreuther et al., 1984). A szakértói módszerekbe sokszor nehéz beépíteni a helyi tudásformákat: a telepítési döntések során használt földrajzi információs rendszerek néha pont olyan információkat nem tartalmaznak, amelyekkel a helyi lakosság körében azonban mindenki tisztában van (Freudenburg, 2004). Az is probléma, hogy a szakértối modellek - a telepítési döntést többdimenziós döntési problémaként értelmezve - megalkotásához olyan súlyokat kell generálnunk, amelyek indoklása még tisztán tudományos szempontból is sokszor kétséges, hiszen az egyes dimenziók számos esetben összemérhetetlenek. A döntési modellek általában igen érzékenyek, ami azt eredményezi, hogy a bemeneti változók kismértékü módosításával (pl. a lakott területektől való minimális távolság változtatásával) az eredmények drasztikusan változhatnak. Végül nem hagyhatjuk figyelmen kívül, hogy biológiai, ökológiai, geológiai stb. tudományos tudásunk sem mindig elégséges ahhoz, hogy a szakértői értékelő csoportok konszenzusra jussanak bizonyos fizikai hatások tekintetében.

\section{A pszichológiai megközelítés}

Sokak szerint a telepítési probléma gyökere az eltéró kockázatpercepciókban és a kockázatkommunikáció eredménytelenségében rejtőzik: a kockázatot a beruházók és a létesítmény más érintettjei eltérően észlelik, illetve interpretálják, és ezek az ellentétes értelmezések gyakran oly mértékben kibékíthetetlenek, hogy feloldhatatlan konfliktushoz vezetnek. Egészen a huszadik század ötvenes éveiig a kockázatokról folyó elmélkedés szinte kizárólag mérnökök és közgazdászok felségterülete volt (utóbbiról késôbb még részletesen lesz szó). $\mathrm{Az}$ ötvenes évektól kezdve azonban sorra jelentek meg olyan tanulmányok, amelyek arra hívták fel a figyelmet, hogy az emberek kockázatészlelései (elsősorban valószínúségbecslései) sokszor jelentékeny mértékben eltérnek azoktól a becslésektól, amelyeket az addig nagy becsben tartott normatív elméletek (mint például a várható hasznosság elmélete) előirányoztak. Az eltéró kockázatpercepciók megközelitése szerint a telepitési probléma elsősorban abból fakad, hogy a telepitók szakértói kockázatészlelése nem egyeztethetó össze a döntés más érintettjeinek laikus kockázatpercepciojával. (A szakértői becslések a kockázatok elóbbiekben bemutatott technikai mértékére vonatkoznak.)

A veszélyesnek, illetve kockázatosnak tartott létesítmények elleni tiltakozások gyökere a megközelítés szerint a felek eltérô kockázatészlelésében keresendő. A kutatások során kiderült, hogy a kockázat koncepciója eltéró csoportoknak teljesen mást jelenthet: feltárták, hogy az értékelés során a laikusok elsôsorban olyan tényezóket vettek figyelembe, hogy az adott kockázati tényező mennyire félelmetes, mennyiben kontrollálható, illetve mennyire újszerú, ismeretlen a tudomány számára (Slovic, 1987). Ezek a kutatások elfogadható magyarázatot szolgáltattak arra az egyre gyakrabban tapasztalt jelenségre, hogy a laikusok egyre többször vetettek el olyan technológiai megoldásokat, létesítményeket, amelyeket a mérnökök eléggé biztonságosnak találtak. A kutatások kimutatták, hogy - noha a laikusok a legtöbb kockázati tényezőt túl magasnak értékelik - a félelmetes, nem kontrollálható és újszerú kockázatok a legkevésbé elfogadhatók a társadalom tagjai számára. A legtöbb veszélyesnek ítélt létesítmény éppen ebbe a kategóriába sorolható, így nem meglepő a széles tár- 
sadalmi elutasítás a fenti beruházásokkal szemben. Az eltéró kockázatpercepciókat vizsgáló kutatási irányzat a telepítési döntéseket övező konfliktusok elsődleges okának tehát nem a valóságos veszélyeket, kockázatokat tartja, hanem az ezekre vonatkozó eltérô észleléseket. Tekintettel arra, hogy a tiltakozók legtöbbször a kockázatokat laikusként szemlélók csoportjából kerülnek ki, így adódik a magyarázat, hogy az ő negatív észlelésük lehet a „kerékkötője” az ilyen jellegú beruházásoknak. A helyzetet tovább bonyolíthatja, hogy maguk a laikusok sem képeznek homogén csoportot: másképp gondolkodhat például egy létesítményról az, aki közvetlenül az új létesítmény mellett lakik, mint az, aki csak a szomszédos településen. Az ó észlelésük a kockázatokról gyökeresen eltérhet.

A kockázatészlelés különbségeit feltáró kutatások eredményeit egy másik döntéspszichológiai kutatási program is alátámasztotta: Daniel Kahneman és Amos Tversky elmélete a heurisztikákról és azok torzító hatásairól (heuristics and biases). Kahneman és Tversky ugyanis azt állították, hogy az emberek valószínúségi becsléseik meghozatalakor leegyszerúsítő hüvelykujjszabályokat alkalmaznak, amelyek szükségképpen torzítják az ítéletalkotásukat (Tversky - Kahneman, 1974). Ezek közül leginkább az ún. hozzáférhetőségi heurisztikát érdemes kiemelni (Tversky - Kahneman, 1973), melynek hatásmechanizmusa szerint valószínuségi becsléseinket nagyban befolyásolja a becsült jelenség felidézhetősége, elérhetősége. A nagyobb balesetek magas médiareprezentációja miatt a veszélyes létesítmények kockázatát a laikusok magasabbnak érzékelik, mint azt a relatív gyakoriságok igazolnák. Mindamellett, hogy a balesetek hírértékük miatt igen eróteljesen jelennek meg a médiában, az sem hagyható figyelmen kívül, hogy számos emblematikus eset ivódott be a nyugati társadalmak kockázattudatába, amelyek a kollektív tudás részét képezik, és bármikor elơhívhatók. A csernobili atomerőmú-katasztrófa, a bhopali vegyianyaggyár balesete vagy az Exxon Valdez olajtanker elsülylyedése Alaszka partjainál mind olyan esetek, amelyek vészharangként megkongathatók a kisebb horderejú esetekben is. A hivatkozott esetek sokszor egyáltalán nem kapcsolódnak az adott telepítési döntéshez, mégis felemlegetésük jelentékeny módon befolyásolhatja az események alakulását (Kunreuther et al., 1984).

$\mathrm{Az}$ eltéró kockázatpercepciókról szóló kutatások nagyon fontos szempontokat adtak hozzá a telepítési döntések körüli konfliktusok feltárásához. Nagyban hozzájárultak ahhoz, hogy megértsük, relatíve biztonságosnak mondott technológiák, létesítmények ellen miért lángol fel újra és újra ellenérzés. Több kérdésre azonban ez a megközelítés sem ad választ. Egyes össze- hasonlító tanulmányok rávilágítottak arra, hogy a negatív kockázatpercepció nem mindig vezet feltétlenül a kockázatosnak tartott létesítmények elutasításához. Másrészt az idő előrehaladtával az ellenzók is próbáltak a támogatókhoz hasonló eszközökhöz nyúlni, így például a másik oldalon is törekedtek olyan szakértối arzenál felállítására, amely képes lehet felvenni a küzdelmet a beruházók szakértői seregével. Az ellenzók szakértői már kevésbé vádolhatók kompetenciahiánynyal, a laikusokra jellemzó szisztematikus torzításokkal kockázatészleléseikben, így nehezen tartható a laikus-szakértő dichotómia a kockázatészlelések közötti különbségek elemzésekor.

Jobban eltávolodva a problémától, feltehetjük a kérdést, egyáltalán hasznos-e az objektív és a szubjektív (észlelt) kockázat közti dichotómia felállítása, illetve a kettő szembeállítása. Ez a megközelítés több esetben ugyanis félrevezetố lehet. Az észlelt kockázatok tana azt sugallja, hogy a kockázatok objektív értelemben általában elfogadhatóak lennének, de az egyének korlátozott kognitív képességeik birtokában ezeket a kockázatokat helytelenül értékelik. Bár ez számos esetben igaz lehet, a legtöbb példa azt igazolja, hogy ezek a kockázatok valóban léteznek, illetve sokszor a tudományos becslések is meglehetôsen bizonytalanok a kockázatok mértékében.

\section{A közgazdasági megközelítés}

A kockázatok elviselésének ára van - hangoztatják a közgazdasági megközelítés hívei. Ennek fényében vállalunk kockázatosabb munkát veszélyességi pótlék fejében, fogadunk el magasabb piaci kockázatokat nagyobb haszon reményében. A telepítési döntések problémájakor szinte mindig felmerül a kompenzáció kérdése, ami a témakörben született publikációk számát tekintve a kutatók egyik legnépszerúbb kutatási területe. A neoklasszikus közgazdaságtan álláspontja szerint, bár elképzelhető, hogy személyek, illetve azok bizonyos csoportjai nem preferálnak egy új létesítményt a lakóhelyük közelében, bizonyos mértékư kompenzáció mellett azonban ez az attitứd megfordul, és az ellenzốk támogatókká válhatnak. A kompenzációs megközelítés elismeri azt, hogy a telepítési döntések során egyes érdekcsoportok ténylegesen rosszabb helyzetbe jutnak, mint az a status quo fenntartásával elérhető lenne. A negatívumok nemcsak észlelt negatív hatások, magasnak észlelt valószínüségek - mint azt a pszichológiai kockázatkutatás teoretikusai állították -, hanem ténylegesen érzékelhetôj jövóbeli hátrányok vagy kockázatok. A kompenzációs megközelítés hívei szerint a telepítési probléma elsósorban abban nyilvánul meg, hogy fel tudjuk-e tárni azt a kompenzációs szintet, amely mellett 
a befogadó közösség tagjai hajlandóak elviselni az új létesítmény okozta kockázatokat, kellemetlenségeket, anélkül, hogy a jolétük szintje romlana.

A kompenzációs szintek ugyanakkor nem feltétlenül egyeznek meg az összes lehetséges befogadó helyszín esetében, így ha a kompenzáció mértékének minimalizálására is törekszünk, akkor azt a mechanizmust is fel kell támunk, amely a legalacsonyabb költségszint mellett biztosítja a nemkívánatos létesítmény elhelyezését. A „mennyit fizessünk és kinek” kérdés megválaszolása azonban további szempontok miatt is problematikus. Különbséget tehetünk ugyanis ex-ante és ex-post kompenzáció között (Kunreuther, 1986), amely arra utal, hogy a befogadó közösség tagjainak (vagy azoknak, akiknek a megnövekedett kockázatokkal, illetve kellemetlenségekkel számolniuk kell) milyen kompenzáció jut a létesítmény megépítése elôtt, illetve az után. Nyilvánvaló, hogy a befogadó közösség tagjai általában maguk is profitálnak az adott létesítmény meglétéből: így például a nem kívánt létesítmény legtöbbször munkahelyet teremt, a helyi adók befizetésével pedig közvetlen bevételt is hoz, és támogatja a helyi közösséget. Ezek ex-post kompenzációs formák, amelyek a beruházás megvalósítása után következnek be. A beruházások ellenzői követeléseikben ugyanakkor a legtöbb esetben az ex-ante kompenzációra helyezik a hangsúlyt, vagyis azokra a juttatásokra, amelyek nélkül a beruházók meg sem kezdhetik terveik megvalósítását.

Bár a beruházók gyakran alkalmazzák a közvetlen anyagi juttatás intézményét, az is elképzelhetô, hogy a kompenzáció nem pénzügyi formában valósul meg, hanem valamilyen természetbeni juttatásként (pl. egy szemétlerakó tulajdonosai ingyenes vagy kedvezményes lerakási lehetôséget biztosíthatnak a befogadó település lakói számára, vagy egy atomerőmú környékén levő településeknek az elektromos áramot csökkentett áron adják el), (Kunreuther et al., 1984)). Bár Magyarországon kevésbé gyakori, de az is elképzelhető, hogy a beruházók garantálják az ingatlanok értékét a befogadó településen, amellyel a tulajdonosokat az esetleges jövoóbeli értékvesztéstől kívánják megvédeni. A befogadó települések kiköthetik azt is - és ez már jellemzóbb hazánkban is -, hogy a leendő létesítmény munkavállalói bizonyos hányadának az adott település lakói közül kell kikerülnie, vagy az ipari egység beszállítóinak egy része helyi beszállító kell, hogy legyen (Minehart - Neeman, 2002). Végül a befogadás ösztönzésére a beruházók gyakran nyúlnak olyan fejlesztési támogatás nyújtásához, amely szorosan véve nem kapcsolódik az új létesítményhez, hanem a település vagy a régió jólétét növeli (úthálózat fejlesztése, iskola, kórház építése stb.).
Fontos kérdés, hogy hogyan osszuk meg a kompenzációt az érdekeltek között. A befogadó település környékén hasonlóan erôs ellenállásra számíthatunk, sốt olykor a környező települések tiltakoznak a legvehemensebben egy veszélyesnek ítélt létesítménnyel szemben. A magyarázat erre a jelenségre az ex-post kompenzáció nem egyenlő elosztása lehet: a helyi adók elsősorban a befogadó települést illetik, és várhatóan az új beruházás is az adott településról szívja fel majd a legtöbb munkaerőt. A környező települések által elviselt kockázatok azonban nagyon hasonlóak azokhoz a kockázatokhoz, amelyek a befogadó települést terhelik. A levegőszennyezés, talajszennyezés, zajterhelés vagy bármely más negatív hatás nem áll meg a befogadó település határainál, hanem a környezó falvakat, városokat is hátrányosan érinti. A környezố települések így joggal várják, hogy a kompenzációból valamilyen mértékben ốk is részesüljenek.

Empirikus tapasztalatok alapján többen megkérdôjelezik, hogy a kompenzáció ténylegesen alkalmas eszköz-e a támogatás megszerzéséhez egy nemkívánatos létesítmény telepítésénél. Az egyik legfontosabb ellenérv a kompenzációval szemben, hogy azt a befogadó közösségek sokszor megvesztegetésként értékelik, amit morálisan elfogadhatatlannak tartanak. Howard Kunreuther, a kompenzációs kérdések egyik ismert teoretikusa szerint éppen ezért hasznosabb lenne a kompenzáció kifejezést pozitívabbra cserélni: ő a hasznok megosztását (benefit sharing) ajánlja a kompenzáció helyett (Kunreuther, 1986), mondván jobban kifejezi a több szerepló közötti alku végeredményét. Howard Kunreuther és Douglas Easterling kutatásai azt bizonyítják, hogy a kompenzációs csomagok vég nélküli emelése nem növeli a kockázatos létesítményeket elfogadók számát, és a létesítmény más jellemzói (kockázatok mértéke, bizalom a létesítménnyel szemben stb.) erősen befolyásolják a kompenzáció sikerét (Kunreuther - Easterling, 1990). ${ }^{4}$ A kompenzáció gyanakvóvá teheti a beruházás civil érintettjeit (Frey et al., 1996), a kompenzációnak ugyanis lehet egy rejtett hatásmechanizmusa is, amely ellenkezó hatást válthat ki a szándékoltakkal szemben. A kompenzáció mértéke ugyanis visszahathat az észlelt kockázatok nagyságára, hiszen a magas kompenzáció azt az érzetet keltheti az emberekben, hogy ténylegesen magas kockázatokra lehet majd számítani a veszélyes létesítmény múködése során.

Vitatható hatékonyságuk ellenére a telepítési döntések során a beruházók nagyon gyakran nyúlnak a kompenzáció eszközéhez, igaz, a legtöbbször nem valamilyen monetáris, hanem - a korábban bemutatott eszköztárból válogatva - valamilyen árnyaltabb formá- 
ban. Több kutatás azt is felvetette, hogy a kompenzációs módszerek akkor alkalmazhatók igazán hatékonyan, ha a kockázatok tényleges csökkentésére irányuló eröfeszítésekkel párosulnak, és a beruházók elszámoltathatók a késóbbi múködés során (a bizalom szerepéról késóbb még részletesen lesz szó). A folyamatos ellenớzés, a tervekbe való beleszólás, illetve problémák esetén a létesítmény bezárásának lehetőségével a kompenzáció sikerének mértéke nagyságrendekkel növelhető (Minehart - Neeman, 2002).

\section{A morálfilozófiai megközelítés}

Tekintettel arra, hogy a telepítési döntések során nagyon sokszor veszélyesnek minősített létesítmények elhelyezéséról kell gondoskodni, szinte minden esetben felmerülnek morális szempontok. A kockázatos létesítmények elhelyezéséről szóló döntések emberek egészségügyi helyzetével vagy akár életével is összefüggésben lehetnek, így sokak szemében a telepítési döntés elsősorban morális dilemma. A morálfilozófiai megközelítés szerint a nemkívánatos létesítmények ellen tiltakoź csoportok elsösorban nem magát a létesitményt utasítják el, hanem az igazságtalan döntési mechanizmust, ahol a legtöbb esetben azokat zárják ki a döntési folyamatból, akikre a döntés eredménye talán a legnagyobb hatással van (Kuhn - Ballard, 1998).

Különböző morálfilozófiai iskolák eltérő válaszokat adnak a telepítési döntésekkel kapcsolatos etikai dilemmákra (Hunold - Young, 1998). Az utilitarista (haszonelvứ) megközelítés szerint a telepítési döntések morálisan szinte mindig igazolhatók, hiszen a társadalmi összhaszon növekedése egy adott létesítmény felépítésével általában nagyobb, mint anélkül. Konfliktusok - mint azt már korábban is érintettem - ugyanis általában olyan létesítményeknél alakulnak ki, amelyek társadalmi szükségességét a legtöbben elismerik, illetve hiánya a társadalomra rendkívül nagy költséget ró. Az utilitaristák álláspontja szerint a befogadó települések lakóinak igaz, hogy kellemetlenségeket és megnövekedett kockázatokat kell elviselniük, ezek költsége azonban még mindig jóval kevesebb, mint az a hasznosságnövekedés, ami egy ilyen vitatott létesítmény megépítésével jár együtt.

Az utilitarista filozófiák egyik legnagyobb fogyatékossága, hogy figyelmen kívül hagyják a javak elosztásának kérdéskörét, nem veszik figyelembe az emberek jogait és önállóságát. A neoklasszikus közgazdaságtan talaján állva azt mondhatnánk, a kockázatokat és a kellemetlenségeket a társadalom azon tagjainak kell elviselniük, akik arra a legalacsonyabb költségek mellett hajlandóak. Éppen ezért az adott kockázatos léte- sítményt ott kell elhelyezni, ahol a legkisebb az igény a kompenzációra. A gondolatmenet egyértelmú következménye, hogy a nemkívánatos létesítményeket általában olyan társadalmi csoportok környezetében kell megépíteni, amelyek szocioökonómiai jellemzői (jövedelmi viszonyok, iskolázottság, várható élettartam stb.) az össztársadalmi átlag alatt maradnak.

Sokszor hallani azt az érvelést, hogy éppen a tiltakozók viselkednek amorálisan, amikor kizárólag saját önérdeküket követve, önző módon elutasítanak egy olyan létesítményt a környezetükben, amelyból az egész társadalom profitálhatna. Ez - folytatódik az érvelés - az állampolgárok részéról potyautas magatartás, hiszen azt szeretnék, ha az előnyöket ôk is élvezhetnék, a költségeket, kockázatokat ugyanakkor más viselné. Vajon elvárható az emberektől, hogy önérdeküket sutba dobva a közjó érdekeit tartsák ilyen esetben szem előtt? Ha elfogadjuk azt az alapelvet, hogy az embereknek joguk van az egészségük megőrzéséhez és a kockázatok méltányos elosztásához, akkor bajosan. Azt sem árt figyelmen kívül hagynunk, hogy sokszor éppen azok a beruházók vádolják önző magatartással a tiltakozókat, akik a telepítési döntés kapcsán busás hasznokat remélnek - a létesítmény megvalósításával általában ók is önérdeküket követik (Freudenburg - Pastor, 1992). A kockázatok társadalmilag igazságos elosztásának problémáját mindemellett kiegészíthetjük a közgazdasági megközelítés kapcsán már tárgyalt másik dilemmával is: hogyan vegyük figyelembe azoknak a környezô településeknek az érdekeit, amelyek közvetlenül nem részesülnek a telepítési döntések áldásos hatásaiból, de a negatívumokat el kell viselniük.

A jogokra alapozott etika talaján állva el kell fogadnunk - de legalábbis mindenképpen mérlegelnünk kell - a tiltakozók álláspontját, akiknek joguk van saját egészségük, környezetük állapotának, vagy éppen ingatlanjaik értékének a megórzéséhez, megvédéséhez. ${ }^{5}$ A felek közötti dialógus első feltétele, hogy a támogatók és az ellenzók egyaránt elismerjék, hogy a másik érvelése, követelése jogos, legitim és teljesen racionális lehet (Schneider et al., 1998). Amennyiben az érintettek ragaszkodnak ahhoz a gyakran hallható álláspontjukhoz, mely szerint a másik fél követelése irracionális, viselkedése pedig érzelmileg túlfưtött, esetleg hisztérikus, úgy lehetetlenné válhat bármilyen további együttmúködés, a konfliktusszituáció rendezése.

A kockázat elosztásával kapcsolatos kérdések azonban az éremnek csak az egyik oldalát képezik. Azt mondhatjuk, hogy ez a telepítési döntések során szubsztantív feltétel, amely elsősorban a döntéshozatal eredményére vonatkozik. A társadalmi igazságosság megítélésekor azonban nem hagyhatjuk figyelmen kí- 
vül azokat a procedurális feltételeket, amelyek a döntéshozatal folyamatára vonatkoznak (Hunold - Young, 1998). Vagyis nem elég morálisan elfogadható, igazságos célokat kitúzni, azokhoz méltányos, igazságos utakon kell eljutni. Az érintettek bevonásáról és annak módjáról a szakirodalomban sincsen egyetértés: a helyi népszavazástól különböző deliberatív (tanácskozó) technikákig igen vegyes a kép. A helyi népszavazás intézménye, amennyiben vétójoggal párosul, igen erős hatalmat ad a helyi közösség kezébe, ezáltal tulajdonképpen a tulajdonosi jogok is a befogadó település kezébe kerülnek. Ezzel - bár a telepítók gyakran próbálnak nyomást gyakorolni a helyiekre - az önkéntesség is fenntartható, ami fontos morális követelmény lehet a meghozott döntéseknél. A deliberatív technikák mindegyik fél számára lehetőséget biztosítanak a tanulásra, más tudásformák megismerésére, fejlesztik a felek konfliktuskezelő képességeit, és kielégítik az elôbbiekben említett procedurális igazságosság követelményeit is (Pataki, 2007).

A társadalmi igazságosság vizsgálatakor az utóbbi két évtizedben egy új szempont is felvetődött. Elsősorban amerikai kutatók kezdtek el vizsgálatokat végezni, amelyek során azt kutatták, hogy a veszélyes, kockázatos üzemek, technológiák elhelyezése általában milyen helyszíneken, illetve milyen társadalmi környezetben történik. Azt tapasztalták, hogy ilyen típusú létesítmények jóval nagyobb valószínúséggel találhatók olyan településeken, régiókban, amelyekre nagyon kedvezőtlen szocioökonómiai mutatók jellemzók, illetve valamilyen (legtöbbször afroamerikai) kisebbség lakja (Wigley - Shrader - Frechette, 1996). Ez a felismerés vezetett a környezetvédelmi igazságosság (environmental justice) és a környezetvédelmi rasszizmus (environmental racism) koncepciójának megalkotásához. Bár vitatható, hogy valóban létezik-e kömnyezetvédelmi rasszizmus, azaz hogy társadalmi csoportoknak börszínük miatt nagyobb kockázatokat, kényelmetlenségeket kell-e elviselniük, az nehezen cáfolható, hogy alacsony jövedelmú régiók, települések, ahol általában az iskolázottság átlagos szintje is alacsonyabb, a munkanélküliség és a búnözés mértéke viszont az átlagnál magasabb, nagyobb eséllyel lesznek valamilyen hátrányos, illetve kockázatos létesítmény befogadói.

\section{Szociológiai megközelítés}

Az előbbi megközelítések a telepítési problémák számos aspektusát tárták fel. Mégis, újabb és újabb telepítési döntések vizsgálatával érdekes jelenségeket figyelhetünk meg. Azt tapasztalhatjuk, hogy amíg Ausztriában szinte lehetetlen lenne az ország bármely pontján atomerômúvet telepíteni, addig Finnországban a közelmúltban viszonylag gyorsan rábólintott a közvélemény egy újabb blokk megépítésére. Egyes országokban - így például hazánkban is - a környezetvédelmi kérdések rendkívül átpolitizáltak, máshol a pártpolitika nem telepszik ennyire rá a „zöld” kérdésekre. Léteznek helyek, ahol a társadalmi intézményekbe vetett bizalom magasabb, másutt igen alacsony. A kockázatkutatás eredményei rávilágítottak arra, hogy a társadalom által észlelt kockázatok általában nem függetlenek a társas normáktól, kulturális hatásoktól, politikai mozgalmaktól vagy éppen a társadalmi intézményektól.

A társadalmi hatások közül elsóként érdemes megemlíteni a társadalmi bizalmatlanság (social distrust) kérdéskörét, amely talán a legtöbbet elemzett témakör a nemkívánatos létesítmények telepítése kapcsán. Empirikus kutatások alátámasztják, hogy a különböző intézményekbe vetett bizalom kulcstényezóje lehet egy kockázatos létesítmény elfogadásának vagy viszszautasításának (Groothuis - Miller, 1997). A központi döntéshozókba, a beruházókba, és általában az általuk szolgáltatott információkba vetett bizalom mértéke nagyban befolyásolhatja, hogy egy helyi referendumon az igen vagy a nem válaszok lesznek többségben, és azt is, hogy a helyi népszavazás intézményét egyáltalán legitim konfliktuskezelési megoldásnak tartják-e az adott közegben. Általánosságban elmondható, hogy a telepítési döntések megvalósításáért felelős társadalmi intézményekbe vetett bizalom mértéke a legtöbb országban igen alacsony, aminek számos oka lehet. Ilyen magyarázó tényező lehet, hogy az elmúlt évtizedek telepítési döntései a legnagyobb jóindulattal sem nevezhetók problémamentesnek, a telepítések múltja a legtöbb esetben nem ad okot a bizalomra. Ennek a fajta bizalomnak a törékenységét a sikertelen telepítési döntések jelzik: a múltbeli bizalmat sokkal könnyebb negatív lépésekkel lerombolni, mint azt újraépíteni (Slovic, 1999). Brian Wynne (1996) szerint a szakértốkbe vetett bizalom hiánya azonban nemcsak a múltbeli negatív eseményeknek, kudarcoknak köszönhetố (jóllehet jelentékeny mértékben hozzájárulnak ahhoz), hanem annak is, hogy a szakértôk és a laikusok legtöbbször teljesen más nyelvet beszélnek (szó szerint, de átvitt értelemben is), más kulturális környezetben mozognak, és véleményeik artikulálásával saját identitásukat kívánják megớrizni. A szakértók csak elvétve hajlandók elismerni a helyi tudásformák értékét, szubjektívnak, laikusnak bélyegezve azt (ahogy arról már az eltéró kockázatpercepciók tárgyalásánál szóltam).

A kulturális hatások és a nemzeti sajátosságok·létét számos tanulmány bizonyítja. Az értékrendszer, a kockázatokról alkotott társas hiedelmek a kockázatos léte- 
sítményekkel szembeni attitúdöket nagymértékben befolyásolhatják, az adott társadalom intézményrendszere pedig könnyítheti, de nehezítheti is a veszélyesnek ítélt létesítmény beruházóinak az ügyét. A kultúra hatását a kockázatészlelésre először Mary Douglas és Aaron Wildavsky vetette fel (Douglas - Wildavsky, 1982). Azt állították, hogy különbözó kulturális környezetben eltérően tekintenek a társadalmat körülvevő kockázatokra, és a kulturális sajátosságok a kockázatok kezelését is meghatározzák. Ha a kockázatokra a kultúra szemüvegén tekintünk, azt sugalljuk, hogy a telepítési döntéseket övezó konfliktusok nem helyi problémák, a lokális keretrendszerben nem feltétlenül érthetốk meg.

A kompenzáció során a kompenzációs formákban részt vevố nagyszámú szereplő, illetve a bonyolult kompenzációs mechanizmusok sokszor nagyon magasra emelhetik a tranzakciós költségeket. Egy ilyen helyzetben az intézmények nagymértékben befolyásolhatják a telepítési döntés sikerét. Japánban például „Kompenzációs Standardok” kialakításával igyekeztek szabályozni a telepítési döntések során felmerüló kifizetéseket, és ez a mechanizmus nagymértékben rányomja bélyegét a szigetországi konfliktusok jellegére. A kompenzáció így formalizált szabályok és eljárások szerint zajlik, elóre kalkulálható, rögzített mértékekkel. $\mathrm{Az}$ érintettek csak a beruházás megkezdésekor kapják meg a kompenzációt, így nem érdekeltek a beruházás halogatásában (Lesbirel, 2003).

A telepítési döntések tárgyalásakor a társadalmi hatások közül a politikai folyamatok szerepét sem hagyhatjuk figyelmen kívül. A politikai folyamatoknak a magyar környezetben - tapasztalataim szerint - még a nyugat-európainál is nagyobb szerepe lehet, a politikusok hozzáállása a különbözó kockázati tényező́khöz döntố lehet azok társadalmi elfogadásában. Az országos politika mellett ugyanakkor a helyi politika lépései sem elhanyagolhatók. A lokális politikai aktivitás nagymértékben befolyásolja, hogy egy adott település, régió miként viselkedik egy nem kívánt létesítménnyel szemben. A létesítménnyel szembeni negatív attitúdök ugyanis még nem feltétlenül váltanak ki éles ellenállást a beruházókkal szemben, annak előfeltétele, hogy meglegyen azoknak az embereknek a kritikus tömege, akik hajlandóak vállalni a tiltakozással járó költségeket, és készek aktívan fellépni a létesítmény gazdáival szemben. A mobilizációs képesség - a helyi lakosság részvétele a tiltakozó akciókban - azonban nemcsak az általános politikai aktivitástól, hanem a meglévő társas hálózatok kiterjedtségétől is függ (a két tényező természetesen nem független egymástól). A meglévó hálózatok (pl. vallási közösségek, nagycsaládok, helyi baráti körök) ugyanis egyrészt csökkenthetik a tiltakozó akciók szervezésének költségeit, másrészt a potyautas magatartás mértékét is limitálják, hiszen a nagyobb kohézió megnehezíti azt az egyének számára (Mitchell - Carson, 1986). Sokszor a politikai szintek sajátos összjátékának is tanúi lehetünk a telepítési döntéseket övezó társadalmi konfliktusok alakulásánál: helyi érdekcsoportok és országos szereplő́k csaphatnak össze, de az is elképzelhetô, hogy helyi csoportosulások fognak össze országosan is ismert szervezetekkel.

A kockázatok észlelése társadalmi szinten is dinamikus folyamat. Nem véletlen, hogy a LULU- vagy NIMBY-jelenség éppen a múlt század 70-es, 80-as éveiben jelent meg, és a kiiktatásukra tett heroikus erôfeszítések ellenére töretlenül jelen vannak a mai napig. A világ iparágai egyre többet és többet költenek a kockázatok menedzselésére, mégis soha nem érezték magukat az emberek még ennyire törékenynek, kiszolgáltatottnak a különböző kockázatokkal szemben (Slovic, 1993). „A rendszer maga rombolja le a bizalmat" - állítja Paul Slovic egyik cikkében (1993): a liberális demokratikus elvek megerősödése, az elektronikus és nyomtatott média robbanásszerú fejlődése és befolyásos speciális érdekcsoportok megjelenése (pl. zöld-szervezetek, jogvédó csoportok) mind abba az irányba hatnak, hogy a társadalom tagjai egyre nagyobb szkepszissel tekintenek a modern technológiákra, új létesítményekre, forradalmi termékekre. A kockázatokról folyó diskurzus, úgy túnik, végérvényesen kicsúszott az ipar, a politika és a tudomány szakértőinek a kezéból.

A beruházóknak, a központi kormányzatoknak nemcsak azért kell bevonniuk az érintetteket, hogy legitimálják tevékenységüket, és a telepítési döntéseket a közvélemény számára is elfogadhatóvá tegyék, hanem hogy olyan diskurzusokat alakítsanak ki, a melyekben lehetơvé válik a rendszerekben való gondolkodás, és így talán a jövoóben nem csak szuboptimális megoldások születnek. Kasperson már 1986-ban a telepítési döntéseket övezó konfliktusok mögött húzódó problémák egyik legfontosabbjaként jelölte meg a rendszergondolkodás hiányát (Kasperson, 1986). A telepítési probléma sokszor abban rejlik, hogy helyi szinten próbál kezelni társadalmi problémákat. Ezzel a problémakezeléssel a telepítók viszont csak részleges sikereket, pirruszi gyózelmeket arathatnak, a társadalmi hatások ugyanis úgy túnik, erösebbek a helyi hatásoknál.

A kockázatok szociológiai megközelítéseivel szemben támasztott ellenvetés elsósorban az, hogy elméleti megalapozottságuk hiányos (Vári, 2005), és nincsen egységes keretrendszer, amelybe illeszkednének az egyes kutatási területek. Bár a különbözó problémafelvetések mindegyike fontos adalékokat adott a kockázatkutatás fejlődéséhez, illetve a telepítési döntések 
kérdéskörének tárgyalásához, önmagában az egyes elméletek - legyen szó a kockázatok kulturális elméletéról vagy a társadalmi bizalmatlanság elméletéról - nem magyarázzák kimerítően a telepítési döntések kudarcait.

\section{Kockázatkommunikációs megközelítés}

Az utolsó megközelítés, amelyet cikkemben tárgyalni fogok, szorosan kapcsolódik az eddig bemutatott öt megközelítéshez, és támaszkodik azok eredményeire. A kockázatkommunikációs megközelítés azt vallja, hogy a telepitési probléma alapvetöen kommunikációs kérdés. A telepítés során a legnagyobb kihívás abban áll, hogyan vehetnénk rá az embereket, hogy befogadjanak egy olyan létesítményt, amelyet nem szeretnének a kertjük mellett tudni. Milyen eszközökkel tudnánk elérni, hogy legalább ne tiltakozzanak a nemkívánatos üzem, technológia ellen? A megközelítés válasza egyértelmú: megfelelő kommunikációval. A felfogásmód talán nem is tekinthető különálló megközelítésnek, hiszen a beruházók számára negatív kockázatpercepciók tompításával éppúgy foglalkozik, mint a közgazdasági előnyök ecsetelésének problémakörével. Mégis az egyik legmarkánsabb irányzatnak nevezhető, amelynek hatásai Magyarországon is erôteljesen érzékelhetốk az utóbbi években. A kockázat kommunikációjáról való gondolkodás kezdetei az 1980-as évek közepére tehetốk, ebben az idôszakban a kutatók még úgy gondolták, hogy megfelelő kommunikációs eszközökkel a telepítési dilemma feloldható (Slovic, 1999). Noha az elmúlt két évtized alatt bebizonyosodott, hogy a kommunikáció korántsem gyógyír minden problémára (Slovic, 1993), azt is látnunk kell, hogy a kockázatkommunikáció több esetben sikereket könyvelhetett el.

A kockázatkommunikációs megközelítés, miképpen az eddig bemutatott megközelítések, a technikai megközelítés ellenpontozásaként alakult ki. A kockázatkommunikáció eszköztára elsősorban azon a bezártságon próbál enyhíteni, amelybe a technokrata telepítési döntési folyamat kényszeríti a beruházókat. A kockázatkommunikáció céljáról ugyanakkor már megoszlanak a vélemények: egyesek szerint a beruházók kezében olyan eszköz, amelynek segítségével elhitetik az érintettekkel, hogy az adott létesítmény negatív hatásai, kockázatai elfogadhatóan alacsonyak, és aggodalomra nem adnak okot. Mások szerint a kommunikációnak a hiteles tájékoztatásra kell törekednie: egyrészt, hogy a laikusok számára elmagyarázza a várható kockázatok mibenlétét, másrészt feltárja a várható kockázatok mértékét, a költségeket a számok nyelvén, végül egyúttal képezze, oktassa is az embereket arra, hogy hogyan minimalizálhatják a kockázatokat, illetve hogyan lehetnek aktív részesei a kockázatok enyhítése folyamatának (Morgan et al., 2002).

A kockázatkommunikáció általában elsődleges feladatának a bizalom és a hitelesség megteremtését tekinti. Peters és szerzôtársai (1997) empirikus kutatásukra támaszkodva arra jutottak, hogy az iparnak a lehetô legnagyobb mértékü törődést és igyekezetet (care and concern) kell mutatnia a kockázati tényezók kezelésekor ahhoz, hogy a bizalmat és a hitelességet kialakítsa. A törődés és az igyekezet az érintettek számára fontosabbnak túnik, mint a tudás és a szakértelem, vagy kissé meglepő módon, mint a nyitottság és az őszinteség. A kormányzati intézményekbe vetett bizalmat elsősorban ezeknek az intézményeknek az elkötelezettsége erősítheti. A civil szervezeteket viszont az teheti hitelesebbé, ha demonstrálni tudják szakértelmüket és tudásukat az adott témában. Azt látjuk, hogy mindhárom szektor azon a területen növelheti a beléje vetett bizalmat és erősítheti hitelességét, ha azokon a területeken fejlődik, amelyekben tradicionálisan a leggyengébb. ${ }^{6}$

A kockázatkommunikáció koncepcióinak középpontjában általában a szakszerü tájékoztatás áll, amely úgy túnik, csakugyan alapfeltétele a bizalom erősítésének. A morális kérdések tárgyalásánál már szóltam viszont arról, hogy az egyoldalú kommunikáció feloldása és az érdekcsoportok bevonása sokat lendíthet azadott létesítmény telepítésének az ügyén. A kooperatív diskurzus módszere (Schneider et al., 1998) három lépcsôben igyekszik áthatolni a szakértők és a laikusok közötti határvonalon, és megvalosítani a helyi emberek részvételét a döntéshozatali folyamatban. A többször sikerrel alkalmazott technika első lépéseként a különböző érdekcsoportok által vallott érdekeket, elvárásokat, értékelési szempontokat gyújtik össze. Ezután azonosítják akülönbözőalternatívákhatásaitéskonzekvenciáit - ezt a fázist külső szakértói csoportok végzik. A harmadik lépcsőfokot a társadalmi döntés jelenti: laikusokból véletlenszerúen választott „esküdtek” választanak a vázolt alternatívákból. Az utolsó fázisban az érdekcsoportok csak tanúként vannak jelen, a döntésbe nem szólhatnak bele, ugyanakkor tajékoztatják, illetve felkészítik a résztvevóket.

Problematikus lehet, hogy sokszor éppen annak a kommunikátornak kellene hitelesen közreadnia a létesítményre vonatkozó információkat, aki a legmotiváltabb abban, hogy a tervezett beruházás megvalósuljon. Miközben saját jogászai bombázzák olyan érvekkel, hogy csak a lehető legkevesebbet árulja el a tervezett fejlesztésről, hogy később minél kisebb eséllyel lehessen ezeket az információkat a telepítő ellen fordítani, addig egyre több jogszabály követeli meg tôle a pontos és teljes körú tájékoztatást. Nem naivitás-e feltételezni, hogy a telepítő minden információt megoszt az 
érintettekkel egy, a legtöbbször végletekig kiélezett helyzetben, amikor tudja, mindig lesz néhány érintett, aki, tegyen és mondjon bármit, úgysem fog hinni neki? A hiteles tájékoztatásra vonatkozó ajánlások, azt látjuk, általában nem valósulnak meg a valós telepítési döntések során, leginkább azért, mert túl sok, egymásnak legtöbbször ellentmondó érdek feszül egymásnak.

\section{Összefoglalás}

William Freudenburg a telepítési döntések sikerét alapvetoóen három tényezőtoól teszi függővé: milyen létesítményról van szó, milyen döntéshozatali folyamatot alkalmaznak a telepítés során, és végül hova kívánják telepíteni, azaz a helyszín milyen közösségi sajátosságokkal bír (Freudenburg, 2004). Különböző létesítmé- nyek elutasítottsága különböző, azok tényleges veszélyességétől és az észlelt kockázatok mértékétól is függ. Utóbbi különbségre világított rá az eltérő kockázatpercepciók tana, amely alapvetően pszichológiai magyarázatokkal szolgál a telepítési döntések kudarcaira. Az elmúlt évtizedekben úgy tứnt, a döntéshozatali folyamat finomításával ezek a kudarcok elkerülhetôk. A befogadó települések, régiók kompenzálása, a méltányos telepítési folyamattal kapcsolatos elvárások kielégítése, a kockázatok párbeszéden alapuló kommunikációja mind olyan eszközök, amelyek a kudarcokból levont tanulságok elemzése után születtek. Az új évezred kezdetén bebizonyosodott, hogy egyik vázolt eszköz sem jelent csodaszert a telepítési problémára, szinte mindegyik újabb - gyakorlati, morális stb. - problémákat vet fel.

A telepítési probléma eltérố megközelítései

1. táblázat

\begin{tabular}{|c|c|c|c|c|c|c|}
\hline & $\begin{array}{l}\text { Technokrata } \\
\text { megközelítés }\end{array}$ & $\begin{array}{l}\text { Pszichologiai } \\
\text { megközelités }\end{array}$ & $\begin{array}{l}\text { Közgazdasági } \\
\text { megközelítés }\end{array}$ & $\begin{array}{l}\text { Morálfilozófiai : } \\
\text { megközelítés }\end{array}$ & $\begin{array}{c}\text { Szociológiai } \\
\text { megközelítés }\end{array}$ & $\begin{array}{c}\text { Kockázat- } \\
\text { kommunikácí́ }\end{array}$ \\
\hline 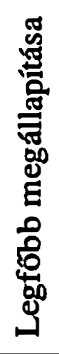 & $\begin{array}{l}\text { - a telepítés } \\
\text { többdimenziós } \\
\text { döntés, ahol } \\
\text { cél az optimá- } \\
\text { lis altematíva } \\
\text { kiválasztása } \\
\text { technikai jellem- } \\
\text { zốk alapján }\end{array}$ & $\begin{array}{l}\text { - a szakértók } \\
\text { kockázat- } \\
\text { becslései nem } \\
\text { egyeztethetốk } \\
\text { össze a laikusok } \\
\text { kockázat- } \\
\text { percepciójával }\end{array}$ & $\begin{array}{l}\text { - a telepítési prob- } \\
\text { léma a megfeleló } \\
\text { kompenzációs } \\
\text { szintek feltárásá- } \\
\text { ból áll, amellett } \\
\text { az érintettek } \\
\text { elfogadják a } \\
\text { létesítményt }\end{array}$ & $\begin{array}{l}\text { - a tiltakozók az } \\
\text { érintettek } \\
\text { kizárást és } \\
\text { a kockázatok } \\
\text { igazságtalan } \\
\text { elosztását } \\
\text { utasítják el }\end{array}$ & $\begin{array}{l}\text { - a telepítés során } \\
\text { észlelt kockáza- } \\
\text { tok nem függet- } \\
\text { lenek a társadal- } \\
\text { mi normáktól, } \\
\text { kultúrától, } \\
\text { intézményektôl }\end{array}$ & $\begin{array}{l}\text { - a telepítési } \\
\text { probléma } \\
\text { alapvetően } \\
\text { kommunikációs } \\
\text { - kérdés }\end{array}$ \\
\hline & $\begin{array}{l}\text { - várható } \\
\text { hasznosságok } \\
\text { kalkulációja, } \\
\text { - szấrốmodellek } \\
\text { alkalmazása, } \\
\text { - szakértốkbe } \\
\text { vetett bizalom, } \\
\text { - többlépcsós } \\
\text { modellek } \\
\text { kifejlesztése }\end{array}$ & $\begin{array}{l}\text { - a laikusok koc- } \\
\text { kázatészlelése } \\
\text { a kockázatok } \\
\text { ismertségétôl és } \\
\text { félelmetességétól } \\
\text { függ, } \\
\text { - heurisztikák } \\
\text { használata a } \\
\text { kockázatbecslés } \\
\text { során, } \\
\text { - kis valószínúsé- } \\
\text { gek torzított ész- } \\
\text { lelése, értelmezé- } \\
\text { si nehézségei } \\
\end{array}$ & $\begin{array}{l}\text { - aukciós mecha- } \\
\text { nizmusok kifej- } \\
\text { lesztése (fizetési } \\
\text { hajlandóság } \\
\text { feltérképezése), } \\
\text { - kompenzáci- } \\
\text { ós csomagok } \\
\text { kialakítása és } \\
\text { tesztelése, } \\
\text { - a kompenzáció } \\
\text { mértékét az } \\
\text { észlelt kockázat } \\
\text { határozza meg }\end{array}$ & $\begin{array}{l}\text { - az utilitarista } \\
\text { modellek meg- } \\
\text { kérdôjelezése, } \\
\text { - a kockázatok } \\
\text { igazságos } \\
\text { elosztásának } \\
\text { problémája, } \\
\text { - hangsúly a mél- } \\
\text { tányos döntési } \\
\text { folyamaton, } \\
\text { - környezetvédel- } \\
\text { mi igazságosság } \\
\text { és rasszizmus } \\
\text { problémák }\end{array}$ & $\begin{array}{l}\text { - társadalmi } \\
\text { bizalmatlanság, } \\
\text { - kulturális } \\
\text { sajátosságok, } \\
\text { - intézményi } \\
\text { standardok } \\
\text { kialakítása, } \\
\text { - politikai } \\
\text { folyamatok, } \\
\text { - rendszer- } \\
\text { gondolkodás } \\
\text { szükségessége }\end{array}$ & $\begin{array}{l}\text { - a bizalom és } \\
\text { a hitelesség } \\
\text { megteremtésének } \\
\text { kérdései, } \\
\text { - objektív adatok } \\
\text { kommunikációja, } \\
\text { - szakszerú } \\
\text { tájékoztatás, } \\
\text { - kooperatív } \\
\text { diskurzus }\end{array}$ \\
\hline 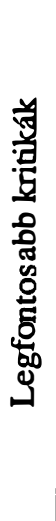 & $\begin{array}{l}\text { - egységesen } \\
\text { elfogadott } \\
\text { módszertanok } \\
\text { hiánya, } \\
\text { - bizonyos } \\
\text { tudásformák } \\
\text { kizárása az } \\
\text { elemzésból, } \\
\text { - dimenziók } \\
\text { összemérése } \\
\text { kétséges }\end{array}$ & $\begin{array}{l}\text { - a negatív kocká- } \\
\text { zatpercepció nem } \\
\text { feltétlenül vezet } \\
\text { elutasításhoz, } \\
\text { - a szakértối } \\
\text { becslések is } \\
\text { korlátozottak, } \\
\text { - nem létezik } \\
\text { objektív } \\
\text { kockázat }\end{array}$ & $\begin{array}{l}\text { - a befogadók } \\
\text { megvesztegetés- } \\
\text { nek érzékelik, } \\
\text {-félelmetes" } \\
\text { kockázatoknál } \\
\text { nem nagyon } \\
\text { múködik, } \\
\text { - az érintetteket } \\
\text { gyanakvóvá } \\
\text { teheti }\end{array}$ & $\begin{array}{l}\text { - a környezetvé- } \\
\text { delmi rasszizmus } \\
\text { koncepciója } \\
\text { erôsen amerikai } \\
\text { gyökerá, } \\
\text { - a versengó } \\
\text { morálfilozófiai } \\
\text { iskolák között } \\
\text { nem lehet igazsá- } \\
\text { got tenni }\end{array}$ & $\begin{array}{l}\text { - a megközelítés } \\
\text { nem alkot egy- } \\
\text { séges egészet, } \\
\text { különbözó } \\
\text { elméletek laza } \\
\text { halmaza, } \\
\text { - a különbözó } \\
\text { felvetések } \\
\text { egyenként nem } \\
\text { magyarázzák a } \\
\text { telepítési dönté- } \\
\text { sek kudarcait }\end{array}$ & $\begin{array}{l}\text { - a tájékoztatás } \\
\text { az érintettek } \\
\text { bevonása nélkül } \\
\text { méltányossági } \\
\text { aggályokat vet } \\
\text { fel, } \\
\text { - az eltéró } \\
\text { érdekeltségek } \\
\text { feloldása } \\
\text { lehetetlennek } \\
\text { tứnik }\end{array}$ \\
\hline
\end{tabular}


A telepítési döntéseket övező társadalmi konfliktusok problémája ugyanis túlmutat egy-egy sikertelen telepítési döntés keretein. Egyfelól a helyi közösségek struktúrája, politikai aktivitása, másfelól az egész társadalom hozzáállása, értékrendje rendkívüli módon leszíkíti a telepítớk mozgásterét, és számos esetben elörevetíti a telepítési döntések kudarcát. Az is megfigyelhető, hogy egy-egy megközelítés neves szerzői egyre többször publikálnak olyan tanulmányokat, amelyek a társadalmi tényező́k szerepét hangsúlyozzák. Az eltérô kockázatpercepciók egyik fő teoretikusának számító Paul Slovic a kilencvenes években a kockázatészlelés pszichológiai kérdései mellett már elsősorban a társadalmi berendezkedéseknek, mozgalmaknak és a médiának a kockázatok percepciójára gyakorolt hatását kutatta (Slovic, 1993; Slovic, 1999). Howard Raiffa, aki korábban a technokrata megközelítés egyik legfeltétlenebb híve volt, kutatótársaival az elmúlt évtizedben a társadalmi igazságosság és a környezetvédelmi raszszizmus kérdéseit vizsgálta, és próbálta beépíteni döntési modelljébe (Field et al., 1996). A különböző megközelítések képviselői, úgy tứnik, nem tudják megkerülni a telepítési döntésekkel kapcsolatos szociológiai tárgyú felvetéseket. (A 1. táblázatban igyekeztem öszszefoglalni a különbözố megközelítések sajátosságait, az elért kutatási eredményeket és a legfóbb kritikákat.)

Tanulmányomban, bár törekedtem a teljes szakirodalmi spektrum bemutatására, nem érinthettem minden alternatív megközelítést. Így az összefoglalóból kimaradt a tranzakciós költségek gazdaságtanának eszköztárával dolgozó érvrendszer bemutatása, ami a negatív externáliák kezelésére, internalizálásának kérdésére helyezi a hangsúlyt, de nem foglalkoztam a konfliktusok tárgykörére fókuszáló megközelítéssel sem, ami a telepítések körüli konfliktusok természetrajzával, annak általános leírásával foglalkozik. Bár a különböző problémákat igyekeztem logikus keretrendszerben bemutatni az előző oldalakon, azok általában nem önmagukban jelennek meg, hanem együtt - egymást sokszor erősítve - a telepítési döntések során.

\section{Lábjegyzet}

1 Ezúton is szeretném megköszönni Pataki György és Harangozó Gábor segítốkész tanácsait, építô jellegú kritikáit. Az írás esetleges hiányosságaiért és tévedéseiért azonban kizárólag a szerzó tartozik felelôsséggel.

2 Ez a definíció összhangban van a mára már klasszikusnak tekinthetô freemani stakeholder-menedzsment megközelítéssel (Freeman, 1993; Boda - Radácsi, 1996).

3 A szûroômodellek és a számszerúsítô modellek különbségeirôl részletesebben lásd Zoltayné Paprika Zita Döntéselmélet címú munkájának (2005) módszertani fejezetét.
${ }^{4}$ Arról nem is beszélve, hogy a kompenzációs költségek emelkedése végsõ soron a telepítés hatékonyságát is megkérdôjelezheti. Azokban az esetekben, amikor a kompenzációs költséget nem kívánják vagy nem tudják a régió más településeire terhelni, akkor a beruházó azzal szembesülhet, hogy fogyasztóival kell megfizettetnie a felmerüló költségeket (állami beruházás esetén esetleg az adófizetôk állhatják a megnövekedett terheket). A túlzottan magas költségek az adott beruházó cég versenyképességét csökkenthetik, amely végül akár meghátrálásra is késztetheti a telepítés során.

5 Az 1950. november 4-én aláirt Emberi Jogok és Alapvetố Szabadságjogok Védelmének Európai Egyezményének 8. cikkelye garantálja mindenkinek a jogát a magánéletének, a családjának és az otthonának tiszteletben tartásához. A dokumentum alapjául szolgált több telepítési konfliktus jogi rendezéséhez (Davy, 1996).

${ }^{6}$ Vagy legalábbis ez a sztereotípia alakult ki a fenti három szektorról: az ipart nem érdekli a természeti környezet, és kevés figyelmet szentel a kömyezeti kockázatoknak, az állami intézmények nem képesek a hosszú távú gondolkodásra, elkötelezôdésre, a civil szervezetek pedig nem rendelkeznek megfelelő szakértelemmel „tudományos” területeken. A kutatás eredményei lehet, hogy csak a jól ismert sztereotípiákat igazolják vissza. Az viszont valószínứsíthetô, hogy a kialakult negatív sztereotípiákat enyhíteni tudó kommunikáció sikeres eszköz lehet a szereplő́k kezében.

\section{Felhasznált irodalom}

Bennedsen, M.B. - Kirkwood, C.W. (1982): Selecting Sites for Coal-Fired Power Plants. Journal of the Energy Division, Proceedings of the American Society of Civil Engineers 108: pp. 69-78.

Boda Zs. - Radácsi L. (1996): Vállalati etika. BKE Vezetôképzô Intézet, Budapest

Chikán A. - Demeter K. (szerk.) (1999): Az értékteremtő folyamatok menedzsmentje. AULA Kiad6, Budapest

Davy, B. (1996): Faimess as Compassion: Towards a Less Unfair Facility Siting Policy. Risk: Health, Safety, and Environment, No. 7, pp. 99-108.

Douglas, M. - Wildavsky, A. (1982): Risk and Culture. University of California Press, Berkeley

Field, P. - Raiffa, H. - Susskind, L. (1996): Risk and Justice: Rethinking the Concept of Compensation. The Annals of the American Academy of Political and Social Science, Vol. 545, No. 1, pp. 156-164.

Freeman, E.R. (1993): Stakeholder-menedzsment. In. A vállalat és múködése. AULA Kiad6, Budapest, pp. 81-94.

Frey, B. - Obleholzer-Gee, F. - Eichenberger, R. (1996): The Old Lady Visits Your Backyard: A Tale of Morals and Markets. Journal of Political Economy, Vol. 104, No. 6, pp. 1297-1313.

Freudenburg, W.R. (2004): Can we learn from failure? Examining US experiences with nuclear repository siting. Journal of Risk Research, Vol. 7, No. 2, pp. 153-169.

Freudenburg, W.R. - Pastor, S.K. (1992): NIMBYs and LULUs: Stalking the Syndromes. Journal of Social Issues, Vol. 48, No. 4, pp 39-61. 
Groothuis, P.A. - Miller, G. (1997): The Role of Social Distrust in Risk-Benefit Analysis: A Study of the Siting of a Hazardous Waste Disposal Facility. Journal of Risk and Uncertainty, Vol. 15, No. 3, pp. 241-257.

Hunold, C. - Young, I.M. (1998): Justice, Democracy, and Hazardous Siting. Political Studies, Vol. 46, No. 1, pp. 82-95.

Kasperson, R.E. (1986): Hazardous Waste Facility Siting: Community, Firm, and Governmental Perspectives. In. Hazards: Technology and Faimess, National Academies Press, Washington D. C.

Kuhn, R.G. - Ballard, K.R. (1998): Canadian Innovations in Siting Hazardous Waste Management Facilities. Environmental Management, Vol. 22, No. 4, pp. 533-545.

Kunreuther, H. (1986): Hazard Compensation and Incentive Systems: An Economic Perspective. In. Hazards: Technology and Faimess, National Academies Press, Washington D. C., pp. 145-163.

Kunreuther, H. - Linneroth, J. - Vaupel, J.W. (1984): A Decision-Process Perspective on Risk and Policy Analysis. Management Science, Vol. 30, No. 4, pp. 475-485.

Kunreuther, H. - Easterling, D. (1990): Are Risk-Benefit Tradeoffs Possible in Siting Hazardous Facilities? The American Economic Review, Vol. 80, No. 2, Papers and Proceedings of the Hundred and Second Annual Meeting of the American Economic Association (May, 1990), pp. 252-256.

Lesbirel, S.H. (2003): Markets, Transaction Costs and Institutions: Compensating for Nuclear Risk in Japan. Australian Journal of Political Science, Vol. 38, No. 1, pp. 5-23.

Minehart, D. - Neeman, Z. (2002): Effective Siting of Waste Treatment Facilities. Journal of Environmental Economics and Management, Vol. 43, No. 2, pp. 303-324.

Mitchell, R.C. - Carson, R.T. (1986): Property Rights, Protest, and the Siting of Hazardous Waste Facilities. AEA Papers and Proceedings, Vol. 76, No. 2, pp. 285-290.

Morgan, M.G. - Fischhoff, B. - Bostrom, A. - Atman, C.J. (2002): Risk Communication: A Mental Models Approach. Cambridge University Press, Cambridge
Pataki Gy. (2007): Bölcs „laikusok” - Társadalmi részvételi technikák a demokrácia szolgálatában. Civil Szemle, Vol. 4, No. 3-4, pp. 144-156.

Peters, R.G. - Covello, V.T. - McCallum, D.B. (1997): The Determinants of Trust and Credibility in Environmental Risk Communication: An Empirical Study. Risk Analysis, Vol. 17, No. 1, pp. 43-54.

Popper, F. (1981): Siting LULUs. Planning, Vol. 47, No. 4, pp. 12-15.

Schneider, E. - Oppermann, B. - Renn, O. (1998): Implementing Structured Participation for Regional Level Waste Management Planning. Risk: Health, Safety \& Environment, Vol. 379, pp. 379-395.

Slovic, P. (1987): Perception of Risk. Science, Vol. 236, pp. 280-285.

Slovic, P. (1993): Perceived Risk, Trust, and Democracy. Risk Analysis, Vol. 13, No. 6, pp. 675-682.

Slovic, $P$. (1999): Trust, Emotion, Sex, Politics, and Science: Surveying the Risk-Assessment Battlefield. Risk Analysis, Vol. 19, No. 4, pp. 689-701.

Tversky, A. - Kahneman, D. (1973): Availability: A heuristic for judging frequency and probability. Cognitive Psychology, 4, pp. 207-232.

Tversky, A. - Kahneman, D. (1974): Judgment under Uncertainty: Heuristics and Biases. Science, New Series, Vol. 185, Iss. 4157, pp. 1124-1131.

Vári Anna (2005): Kockázat. In. Zoltayné Paprika Zita: Döntéselmélet. Alinea Kiadó, Budapest

Wigley, D.C. - Shrader-Frechette, K. (1996): Environmental Racism and Biased Methods of Risk Assessment. Risk, Health, Safety \& Environment, Vol. 55, No. 4, pp. 55-88.

Wynne, B. (1996): Misunderstood misunderstandings. In. Irwin, A.-Wynne, B. (szerk.): Misunderstanding Science?: The Public Reconstruction of Science and Technology. Cambridge University Press, Cambridge, UK, pp. 19-46.

Zoltayné Paprika Z. (2005): Döntéselmélet. Alinea Kiadó, Budapest

Cikk beérkezett: 2008 4. hó

Lektori vélemény alapján véglegesítve: 2008 . 5. hó 